\title{
KEPATUHAN PEJABAT TATA USAHA NEGARA MENJALANKAN PUTUSAN PENGADILAN TATA USAHA NEGARA BERDASARKAN ASAS-ASAS PEMERINTAHAN YANG BAIK
}

\author{
Basuki Kurniawan ${ }^{1}$, Sholikul Hadi ${ }^{2}$ \\ Fakultas Syariah Institut Agama Islam Negeri (IAIN) Jember, Jember, \\ Jl. Mataram No.1, Karang Miuwo, Mangli, Kecamatan Kaliwates, Kabupaten \\ Jember, Jawa Timur 68136, Indonesia I basukikurniawanlaw@gmail.com \\ DOI: https://doi.org/10.35719/ijl.v1i2.96
}

Abstrak : The title of this journal Court Based On Good Goverment Principles. The main problems to be studied are: (1) how the legal obedience of administrative officials carry out the verdict of administrative court based on good government principles? ; (2) Is the arrangement about the obedience of administrative officials already appropriate with good government principles?.

The method of study use is the juridical normative method. The Approaching of problems use statute approach, conseptual approach, and case approach. Research data source is taken from primary and secondary legal materials. The collected data is qualitatively analyzed by a normative juridical approach.

The result of this research are : first, the legal obedience of administration officials is to be consistent do the verdict of administrative court in the framework of implementation good good government principles. The obedience based on legal awareness. Legal awareness and legal obedience very needed for law enforcement in Indonesia. Awareness and legal obedience very needed by every person, in the same manner as the purpose of law. The administrative officials as people which have positions needed to be stressed for being obedience the verdict of administrative court based on good government principles and alse as example to other people. Second, based on article 116 Law Number 5 Year 1986 about Administration Court cpuld be understood that the arrangement obedience the

\section{IJLIL: INDONESIAN JOURNAL OF LAW AND ISLAMIC LAW VOLUME 2 NOMOR 1 JANUARI-JUNI 2020; \\ ISSN 2721-5261 E-ISSN 2775-460X}


administrative officials not appropriate with good government principles.

Based on the research result is recommended, that first, the Administration court based on Law Number 5 Year in the essence is good enough. The obedience of administrative officials still less make the verdict of administration court no run well, so needed to make birocration reformation especially to the interpretation of the legal awareness or increasing awareness from government to all administrative officials as formed the respect existence to the body of government; second, Inobedience the administrative court to the verdict of administration court could be categorize criminal. Third, for the verdict of administration court be able to be done well by administrative officials, so needed control body, although internal and external, hereby the duty of Obudsman National Commision very importence to give attention to the administrative official to do the verdict of administration court. Keywords: The Obedience Of Administrative Officials, Administrative Court, Good Government Principles

\section{Pendahuluan}

Indonesia merupakan negara hukum', konsekuensi logis dari negara hukum adalah pelaksanaan pemerintahan di Negara Indonesia harus berdasarkan hukum. Hukum di Indonesia merupakan campuran dari sistem hukum Eropa, hukum agama, dan hukum adat. ${ }^{2}$ Peneliti dalam penulisan karya ilmiah ini lebih menekankan tentang pentingnya penegakan hukum positif untuk seluruh rakyat Indonesia. Maksud dan tujuan dari konsepsi negara hukum adalah untuk

\footnotetext{
${ }^{1}$ Undang-Undang Dasar Negara Republik Indonesia Tahun 1945, Pasal 1 Ayat (3) yang menyatakan bahwa: Negara Indonesia adalah negara hukum.

${ }^{2}$ Hukum di Indonesia, https://id.wikipedia.org diakses pada tanggal 1 Pebruari 2016.
} 
memberikan perlindungan dan keadilan serta kesejahteraan

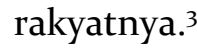

Hukum menghadirkan diri dalam wujud kaidah yang disebut kaidah hukum (rechtsnorm, legal norm), yang penampilannya dapat berbentuk tertulis (dirumuskan dalam rangkaian kata-kata yang tertata sesuai dengan sintaksis yang berlaku) maupun tidak tertulis (yang tampil dalam wujud perulangan perilaku yang sama tiap terjadi situasi yang sama).4

Peradilan Tata Usaha Negara yang sering disebut dengan PTUN adalah bukti sahih adanya negara hukum di Indonesia. Peraturan hukum di Indonesia tidak hanya mengatur warga negara pada umumnya, tetapi pejabat negara juga ikut masuk dalam peraturan hukum. Hal ini merupakan konsekuensi logis dari sebuah bentuk negara hukum yang di anut oleh para the founding fathers dan mothers Republik Indonesia. Diantara para founding father's dan kemudian tercapai kesepakatan untuk mendirikan sebuah Negara yang bernama Indonesia, pada saat itu pula bangsa ini menyadari bahwa keadilan merupakan hal yang penting untuk memajukan suatu bangsa. ${ }^{5}$

3Widodo Ekatjahjana, Negara Hukum, Konstitusi, dan Demokrasi (Dinamika dalam Penyelenggaraan Sistem Ketatanegaraan Republik Indonesia),(Jember: Jember University Press, 2015), 63.

4Bayu Dwi Anggono, Perkembangan Pembentukan Undang-Undang Di Indonesia, (Jakarta: Konstitusi Press, 2014), 1.

5Pembukaan UUD NRI Tahun 1945 yang dirumuskan: “...melindungi segenap bangsa Indonesia dan seluruh tumpah darah Indonesia dan memajukan kesejahteraan 
Pejabat Tata Usaha Negara atau sering kali disebut dengan Pejabat TUN, tidak bisa lepas dari tanggung jawab hukum bilamana pejabat TUN melaksankan kebijakan bertentangan dengan undang-undang dan Asas-Asas Pemerintahan yang Baik. Asas-asas pemerintahan yang baik merupakan asas-asas yang menjadi pedoman apakah pejabat tata usaha Negara tersebut sudah sesuai atau belum dengan norma yang ada dalam menjalankan tugas jabatannya.

Pengaturan kedudukan Pengadilan Tata Usaha Negara secara tegas dalam konstitusi tersebut dipengaruhi oleh gagasan mengenai perlunya peningkatan kualitas pengawasan terhadap pemerintah, sejalan dengan semakin meningkatnya tugas-tugas yang harus dilaksakan oleh Pemerintah yang dipengaruhi oleh paham negara kesejahteraan (welfare state). Sejalan dengan berkembangnya pemaknaan fungsi dan tugas negara kesejahteraan (welfare state) dalam paham negara hukum modern (modern rechtstaat) maka fungsi Peradilan Tata Usaha Negara untuk melakukan pengawasan terhadap pemerintah semakin meningkat baik ditinjau dari segi kualitas maupun kuantitas pengawasannya. ${ }^{6}$

Tradisi peradilan yang dikenal saat ini mempunyai

umum, mencerdaskan kehidupan bangsa dan ikut melaksanakan ketertiban dunia berdasarkan perdamaian abadi dan keadilan social".

6 W. Riawan Tjandra "Peradilan Tata Usaha Negara, Mendorong Terwujudnya Pemerintahan yang Bersih dan Berwibawa, (Yogyakarta: Penerbit Universitas Atmajaya Yogyakarta, 2009), 1. 
sejarah yang cukup panjang. Sistem yang berlaku di suatu peradilan memiliki tingkat saling terkait dengan sejarah hukum yang dimiliki suatu negara. Harus diakui, bahwa sistem peradilan yang digunakan di Indonesia sebagaimana yang dikenal saat ini, tidak bisa lepas dari sistem peradilan yang dianut oleh Belanda.Sistem peradilan di Indonesia setelah diadakan perubahan Pasal 24 yang berkaitan dengan kekuasaan kehakiman Undang-Undang Dasar Negara Republik Indonesia Tahun 1945 selanjutnya disebut UUD NRI Tahun 1945 menyatakan:

(1) Kekuasaan kehakiman merupakan kekuasaan yang merdeka untuk menyelenggarakan peradilan guna menegakkan hukum dan keadilan.

(2) Kekuasaan kehakiman dilakukan oleh sebuah Mahkamah Agung dan badan peradilan yang beradi dibawahnya dalam lingkungan peradilan umum, lingkungan peradilan agama, lingkungan peradilan militer, lingkungan peradilan tata usaha negara, dan oleh sebuah Mahkamah Konstitusi.

Peradilan Tata Usaha Negara yang berada di bawah yurisdiksi Mahkamah Agung menjadi bagian penting dalam penegakan peradilan antara seseorang atau badan hukum perdata yang merasa kepentingannya itu dirugikan oleh suatu keputusan tata usaha negara. ${ }^{7}$ Proses beracara di PTUN itu

7 Dalam praktik pemerintahan di Indonesia bentuk keputusan tata usaha Negara 
menyidangkan suatu keputusan pejabat TUN yang dianggap merugikan rakyat perorang atau kelompok.

Putusan PTUN menjadi bentuk suatu koreksi bahwa keputusan pejabat $\mathrm{TUN}^{8}$ yang terbentuk dalam kebijakan Surat Keputusan, penetapan, dan lain-lain terdapat kesalahan. Hal ini membuktikan bahwa tidak ada siapapun di Indonesia yang kebal hukum. Pejabat negara yang berada di lembaga eksekutif 9 mempunyai kedudukan yang sama di hadapan hukum.

Bentuk putusan yang dikeluarkan PTUN kemudian bisa di ajukan banding dan kasasi bilamana pejabat TUN merasa putusan tersebut tidak adil. Karena memang tujuan adanya peradilan adalah untuk mencapai keadilan. Bilamana tidak diajukan banding selama empat belas hari, maka putusan PTUN itu mempunyai kekuatan hukum tetap/inkracht. Putusan PTUN yang sudah mempunyai kekuatan hukum tetap wajib dilaksanakan oleh tergugat dan penggugat.

sangat beraneka ragam. Contoh: SK Pengangkatan Pegawai, Izin Usaha Industro, Surat Keterangakan Kelakuan Baik, Akte Kalahiran, Surat Izin Mengemudi (SIM), Sertifikat Hak Atas Tanah dll.

$8 \quad$ UU No. 51 Tahun 2009 tentang Perubahan Kedua Atas UU No. 5 Tahun 1986 tentang Peradilan Tata Usaha Negara, Pasal 1 Angka 9 :"Keputusan Tata Usaha Negara adalah suatu penetapan tertulis yang dikeluarkan oleh badan atau pejabat tata usaha negara yang berisi tindakan hukum tata usaha negara yang berdasarkan peraturan perundang-undangan yang berlaku, yang bersifat konkret, individual, dan final, yan menimbulkan akibat hukum bagi seseorang atau badan hukum perdata".

9 Teori Montesqiueu menjelaskan bahwa teori trias politika yang terdiri dari eksekutif, legislatif dan yudikatif. Tujuan dari ketiga badan tersebut adalah terbentuknya check and balance diantara lembaga negara. Lihat I Dewa Gede Atmadja, Ilmu Negara, (Malang: Setara, 2012), 100. 
Fenomena yang terjadi di masyarakat dapat ditelisik dari berbagai media online dan cetak, terdapat beberapa putusan PTUN yang sudah mempunyai kekuatan hukum tetap itu tidak dilaksanakan oleh pejabat TUN. ${ }^{10}$ Hal ini menjadi bukti bahwasannya terjadi penyelewangan hukum yang terjadi di kalangan pejabat negara yang mempunyai posisi sebagai lembaga eksekutif.

Pertanyaan yang muncul adalah kenapa pejabat TUN tidak berkenan melaksanakan putusan PTUN yang sudah berkekuatan hukum tetap. Padahal dalam UU RI Nomor 51 Tahun 2009 tentang Perubahan Kedua atas Undang-Undang Nomor 5 Tahun 1986 tentang Peradilan Tata Usaha Negara, Pasal 116 menyatakan bahwa:

(1) Salinan putusan pengadilan yang telah memperoleh kekuatan hukum tetap, dikirimkan kepada para pihak dengan surat tercatat oleh panitera pengadilan setempat atas perintah ketua pengadilan yang mengadilinya dalam tingkat pertama selambat-lambatnya dalam waktu 14 (empat belas) hari kerja.

(2)Apabila setelah 6o (enam puluh) hari kerja putusan pengadilan yang telah memperoleh kekuatan hukum tetap sebagaimana dimaksud pada ayat (1) diterima tergugat tidak melaksanakan

\footnotetext{
${ }^{10}$ www.yomawaperatun.blogspot.com , diakses pada tanggal 1 April 2015.
} 
kewajibannya sebagaimana dimaksud dalam Pasal 97 ayat (9) huruf a, keputusan tata usaha negara yang disengketakan itu tidak mempunyai kekuatan hukum lagi.

(3) Dalam hal tergugat ditetapkan harus melaksanakan kewajiban sebagaimana dimaksud dalam Pasal 97 ayat (9) huruf b dan huruf c, dan kemudian setelah 90 (sembilan puluh) hari kerja ternyata kewajiban tersebut tidak dilaksnakan, maka penggugat mengajukan permohonan kepada ketua pengadilan sebagaimana dimaksud pada ayat (1), agar pengadilan memerintahkan tergugat melaksanakan putusan pengadilan.

(4)Dalam hal tergugat tidak bersedia melaksanakan putusan pengadilan yang telah memperoleh kekuatan hukum tetap, terhadap pejabat yang bersangkutan dikenakan upaya paksa berupa pembayaran sejumlah uang paksa dan/atau sanksi administratif.

(5) Pejabat yang tidak melaksanakan putusan pengadilan sebagaimana dimaksud pada ayat (4) diumumkan pada media massa cetak setempat oleh panitera sejak tidak terpenuhinya ketentuan sebagaimana dimaksud pada ayat (3)

(6)Di samping diumumkan pada media massa cetak 
setempat sebagaimana dimaksud pada ayat (5), ketua pengadilan harus mengajukan hal ini kepada Presiden sebagai pemegang kekuasaan pemerintah tertinggi untuk memerintahan pejabat tersebut melaksanakan putusan pengadilan, dan kepada lembaga perwakilan rakyat untuk menjalankan fungsi pengawasan.

(7) Ketentuan mengenai besaran uang paksa, jenis sanksi administratif, dan tata cara pelaksanaan pembayaran uang paksa dan/atau sanksi administratif diatur dengan peraturan perundangundangan.

Pasal 116 UU RI No. 51 Tahun 2009 tersebut bila diteliti terjadi belum ada kepastian hukum. Pasal 116 Ayat (4) yang menerangkan dengan "pejabat yang bersangkutan dikenakan uang paksa”, uang paksa yang dimaksud pada ayat tersebut belum tertulis jumlah nominal yang diwajibkan. Sehingga terjadinya multitafsir dalam pengenaan uang paksa, sebab antara pejabat TUN dengan rakyat biasa tentang besaran uang paksa tentu sangat berbeda.

Pasal 116 Ayat (5) yang menegaskan tentang "pengumuman di media massa cetak setempat", juga masih belum memberikan efek jera bagi pejabat TUN yang tidak melaksanakan putusan PTUN. Hal ini disebabkan karena bila hanya ditingkat lokal maka rasa malu dan mau melaksanakan 
putusan PTUN sangat sulit diharapkan untuk dilaksanakan.

Permasalahan yang terjadi dimasyarakat menjadikan bukti bahwa UU Peradilan TUN masih kurang mempunyai law enforcement di masyarakat. Hal tersebut bisa diteliti dari UU PTUN yang telah diubah dua kali belum mempunyai kekuatan pada eksistensi putusannya.

Rekomendasi yang dikeluarkan oleh Ombudsman Republik Indonesia dengan tertulis dalam Nomor : 003/REK/0899.2009/BS.03/III/2012 yang telah menerima laporan/pengaduan dari Dr. Ir. Julius Pontih, M.Sc yang bekerja di FMIPA Universitas Sam Ratulangi, Manado, mengenai tidak dilaksanakannya Putusan PTUN Manado yaitu Nomor 27/G.TUN/2006/PTUN.MDO jo 43/B.TUN/2007/PT/TUN.MKS yang rekomendasikan terhadap rektor Universitas Sam Ratulangi agar melaksanakan putusan PTUN tersebut." Hal ini menjadi contoh bahwa penegakan hukum administrasi Negara perlu ditingkatkan, khususnya dengan adanya lembaga Ombudsman Republik Indonesia.

Peradilan TUN merupakan peradilan yang menjunjung tinggi asas-asas umum pemerintahan yang baik bagi pejabat TUN. Asas-asas pemerintahan yang Baik merupakan penerjemahan dari istilah dalam hukum adminitrasi di

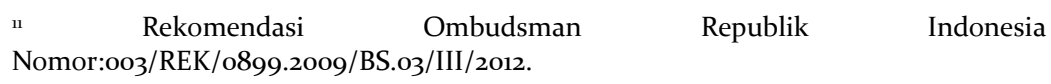


Belanda yaitu "Algemene Beginselven van Behoorlijk Bestuur" atau mempunyai arti dalam bahasa Inggri disebut sebagai "the principles of good administration". dalam berbagai undangundang yang menguasai peradilan administrasi di Nederland, asas-asas umum pemerintahan yang baik (ABBB) disebut sebagai dasar banding dan atau pengujian (antara lain Pasal 8 ayat 1 di bawah Wet AROB). ABBB adalah asas-asas hukum tidak tertulis, dari mana untuk keadaan-keadaan tertentu dapat ditarik aturan-aturan hukum yang dapat diterapkan. ${ }^{12}$

Pejabat TUN dalam menjalankan tugas dan wewenang sebagai pejabat Negara dibatasi oleh asas-asas pemerintahan yang baik, sehingga di harapakan dengan adanya asas-asas pemerintahan yang baik, bentuk kepastian hukum bagi setiap warga Negara dapat tercapai, tanpa adanya suatu diskriminasi sama sekali. Wiarda mengemukakan mengenai Asas-asas umum pemerintahan yang baik sebagai berikut:

Asas-asas Umum Pemerintahan yang Layak itu sebagai tendens-tendens etik, yang menjadi dasar hukum adminstrasi kita, baik yang tertulis maupun yang tidak tertulis, termasuk praktek pemerintahan, dan dapatlah diketahui pula bahwa asas-asas itu untuk sebagian dapat diturunkan dari hukum dan praktek itu, sedangkan untuk sebagian secara eviden langsung mendesak kita.

Kurangnya kepatuhan pejabat TUN dalam

\footnotetext{
${ }^{12}$ Philipus M.Hadjon, et.al, Pengantar Hukum..., op.cit, 270.
} 
melaksanakan putusan PTUN berdasarkan asas-asas pemerintahan yang baik menjadi permasalahan tersendiri dalam segi penegakan hukum. Hal tersebut dikarenakan setiap warga negara mempunyai kedudukan yang sama di hadapan hukum, tidak ada yang lebih khususkan. Pejabat TUN sebagai warga negara Indonesia juga mempunyai hak yang sama seperti warga pada umum. Akibat hukum dari tidak patuhnya pejabat TUN dalam melaksanakan putusan PTUN akan menjadikan rakyat akan menyepelekan peradilan dan hukum di Indonesia.

Peneliti ingin meneliti tentang kepatuhan pejabat TUN untuk menjalankan putusan Pengadilan Tata Usaha Negara berdasarkan Asas-Asas Pemerintahan yang Baik.Sehingga menjadikan putusan Peradilan Tata Usaha Negara dapat menjadi peradilan yang tangguh sebagai pengawal terwujudnya Aparatur Negara yang tertib, efisien, berwibawa dalam rangka Negara Hukum Republik Indonesia.

\section{Metode Penelitian}

Suatu penelitian ilmiah mutlak menggunakan metode, karena metode itu berarti penyelidikan yang berlangsung menurut suatu rencana tertentu. Menempuh suatu jalan tertentu untuk mencapai suatu tujuan, artinya peneliti tidak bekerja secara acak-acakan melainkan setiap langkah yang diambil harus jelas serta ada pembatasan-pembatasan tertentu untuk menghindari jalan yang menyesatkan dan 
tidak terkendalikan. ${ }^{13}$ Demikian pula dalam penelitian ini, digunakan langkah-langkah penelitian sebagai berikut :

Penelitian ini digunakan tipe penelitian yuridis normatif. Hal ini sebagai konsekuensi pemilihan topik permasalahan yang akan dikaji. Adapun maksud dari tipe penelitian tersebut akan di konsentrasikan pada kaidahkaidah atau norma-norma yang ada didalam hukum positif atau hukum yang sedang berlaku pada saat sekarang dan yang berada di Indonesia. Dengan demikian terjadilah suatu persesuaian kehendak atau adanya suatu korelasi antara segala permasalahan yang terdapat pada rumusan masalah yang telah di tetapkan dari isu-isu hukum dengan normanorma hukum yang sedang berlangsung. Adapun penelitian hukum ini dilakukan untuk memecahkan isu hukum yang timbul, sedangkan hasil yang akan di capai dari sebuah penelitian hukum tersebut adalah preskripsi mengenai apa yang seyogyanya atas isu hukum yang diajukan. ${ }^{14}$

Sehubungan dengan tipe penelitian yuridis normatif maka pendekatan masalah yang paling tepat adalah pendekatan perundang-undangan (Statute Approach). Pendekatan ini di maksudkan melakukan pengkajian peraturan perundang-undangan yang berhubungan dengan pokok bahasan, yaitu dengan menganalisis aturan hukum

\footnotetext{
13 Johny Ibrahim, Teori dan Metodologi Penelitian Hukum Normatif, (Malang : Bayumedia, 2006), 294.

${ }^{14}$ Peter Mahmud Marzuki, Penelitian Hukum, ( Jakarta : Kencana, 2008), 41.
} 
yang terkait, terutama aturan hukum. Disamping itu juga digunakan pendekatan konseptual (Conseptual Approach) yaitu dengan cara mengindetifikasi dan menganalisa konsepkonsep hukum dalam teori maupun praktik. Kemudian pendekatan masalah yang digunakan penulis adalah pendekatan kasus (case approach), dalam menggunakan pendekatan kasus, yang perlu dipahami oleh peneliti adalah ratio decidendi, yaitu alasan-alasan hukum yang digunakan oleh hakim untuk sampai kepada putusannya. ${ }^{15}$

\section{Pembahasan}

\section{Pengertian Pengadilan Tata Usaha Negara.}

Hukum tata usaha negara yang mengatur seluruh warga negara dalam bentuk adminsitratif. Penegakan hukum tata usaha negara supaya mempunyai posisi hukum yang ada maka dibentuklah Pengadilan Tata Usaha Negara. Berawal dari kata peradilan yang terdiri dari kata dasar "adil" dan mendapatkan awalan "per-“ serta akhiran "-an”, berarti sesuatu yang berkaitan dengan pengadilan. ${ }^{16}$ Pengadilan disini bukanlah diartikan semata-mata sebagai badan untuk mengadili,melainkan sebagai pengertian yang abstrak, yaitu "hal memberikan keadilan", artinya peradilan adalah segala

\footnotetext{
${ }^{15}$ Ibid, 144.

${ }^{16}$ Sudikno Mertokusumo, Sejarah Peradilan dan Perundang-Undangannya di Indonesia Sejak 1942 dan Apakah Kemanfaatannya Bagi Kita Bangsa Indonesia, Disertasi, (Yogyakarta: Liberty, 1983), 2-3.
} 
sesuatu yang bertalian dengan tugas hakim dalam memutus perkara, baik perkara perdata, pidana maupun tata usaha negara, untuk mempertahankan atau menjamin ditaatinya hukum materiil. ${ }^{17}$ Dalam mengartikan "peradilan" ia menunjuk kepada sekurang-kurangnya dua dari tiga ciri, yaitu: a) adanya peristiwa individual yang ditangani; b) adanya norma yang berlaku yang diterapkan; dan c) adanya konflik yang disalurkan. ${ }^{18}$

Pengadilan Tata Usaha Negara (PTUN) disebut juga pengadilan administrasi negara. PTUN lahir dan mulai bekerja melayani masyarakat pencari keadilan sejak 14 Januari Tahun 1991. Pengadilan Tata Usaha Negara (PTUN) adalah pengadilan yang termuda di antara 4 (empat) lingkungan peradilan (Pengadilan Negeri; Pengadilan Militer; Pengadilan Agama dan Pengadilan Tata Usaha Negara). Indonesia sebagai negara hukum sudah lama mencita-citakan untuk membentuk pengadilan administrasi negara atau Pengadilan Tata Usaha Negara. Rencana pembentukan tersebut dicantumkan baik dalam Undang- Undang Dasar, undangundang maupun Garis-Garis Besar Haluan Negara. ${ }^{19}$

Permasalahan mengenai hubungan antara hakim

\footnotetext{
${ }^{17}$ Ibid.

18 A. Hamid S.Attamimi, Teori Perundang-Undangan Indonesia, Suatu Sisi Ilmu Pengetahuan Perundang-Undangan yang Menjelaskan dan Menjernihkan Pemahaman, Pidato di Fakultas Hukum Universitas Indonesia, Jakarta, 25 April 1992, 5, lihat Herowati Poesoko, 117.

${ }^{19 L i n t o n g ~ O . ~ S i a h a a n, ~ P r o s p e k ~ P T U N ~ S e b a g a i ~ P r a n a t a ~ P e n y e l e s a i a n ~ S e n g k e t a ~}$ Administrasi di Indonesia (Studi Tentang Keberadaan PTUN Selama Satu Dasawarsa 1991-2001, (Jakarta: Percetakan Negara RI, 2005), xii.
} 
administrasi dan berfungsinya pemerintahan, oleh seorang penulis dan sekaligus Hakim Agung Administrasi terkenal di Perancis, R. Odent sebagaimana dikutip oleh Paulus Effendie Lotulung antara lain sebagai berikut: ${ }^{20}$

"The closeness between administration and judge is seen as the foundation of the ability if the administrative courts to set standards which will be seen as appropriate and be implemented by the administration". ${ }^{21}$

Sesuai dengan pendapat tersebut, dengan perkataan lain dapat dikatakan bahwa peranan peradilan administrasi melalui putusan-putusannya pada hakikatnya dapat menentukan ukuran dan nilai-nilai hukum sehingga akan memberikan arah pada erciptanya suatu pemerintahan yang baik (good Administration), didasarkan pada hukum dan etika pemerintahan. ${ }^{22}$ Juga ciri yang ada tersebut merupakan tugas hakim. Secara tegas tugas hakim dalam mengemban tugas pokok peradilan adalah menerima, memeriksa, mengadili (menentukan) serta menyelesaikan setiap perkara.

\footnotetext{
${ }^{20}$ Paulus Effendie Lotulung, Eksistensi Undang-Undang Nomor 5 Tahun 1986 Dalam Menunjang Pemerintahan yang Bersih, Kuat dan Berwibawa dalam "Butir-Butir Gagasan Tentang Penyelenggaraan Hukum dan Pemerintahan Yang Layak (Sebuah Tanda Mata Bagi 70 Tahun Prof. Dr. Ateng Syarifudin, S.H.), (Bandung: PT. Citra Aditya Baktim 1996), hlm. 327., lihat juga L. Neville Brown, cs, French Administrative Law,fourth edition, (Oxford: Clarendon Press, 1993), 41.

${ }_{21}^{21}$ Terj. Pendekatan anatara administrasi dan hakim dilihat sebagai suatu dasar kemampuan bilamana peradilan tata usaha negara diatur standar yang mana akan dilihat secara tepat dan dilaksanakan oleh administrasi/tata usaha negara.

${ }^{22}$ L. Neville Brown, cs, French Administrative Law,fourth edition, (Oxford: Clarendon Press, 1993), 328.
} 
Pada hakikatnya hakim hanya diminta atau diharapkan untuk mempertimbangkan benar tidaknya peristiwa yang diajukan kepadanya, tetapi hakim dalam menjalankan tugasnya harus bersikap adil bagi para pihak yang berperkara dan menjalankan tugasnya sesuai dengan hukum acara perdata yang berlaku, karena hukum acara perdata pada asasnya bersifat mengikat. ${ }^{23}$ Maka oleh karena itu hakim sebagai stabilisator hukum. ${ }^{24}$

Peradilan Tata Usaha Negara atau sering disebut dengan PTUN merupakan sayap kewenangan baru di lingkungan peradilan dibawah Mahkamah Agung. Babak baru ini dimulai sejak tahun 1991 berdasarkan ketentuan dalam Pasal $144^{25}$ Undang-Undang Nomor 5 Tahun 1986 tentang Peradilan Tata Usaha Negara (Lembaran Negara Republik Indonesia Tahun 1986 Nomor 77, Tambahan Lembaran Negara Republik Indonesia Nomor 3344), selanjutnya disebut UU PTUN.

Perihal pengaturan PTUN mengalami perubahan seiring dengan empat tahap perubahan UUD 1945 pada tahun 1999-2002, perubahan undang-undang yang mengatur Kekuasaan Kehakiman dan Mahkamah Agung.

${ }_{23}$ C.W. Star Busmann, Hoofdstukken van Burgerlijke Rechtsvordering, No. 18.

${ }^{24}$ Sunaryati Hartono, Peranan Peradilan ....,op. cit, 8.

${ }^{25}$ Lihat Rumusan Pasal 144 UU Nomor 5 Tahun 1986 yakni : "Undang-Undang ini mulai berlaku pada tanggal diundangkan dan penerapannya diatur dengan Peraturan Pemerintah selambat-lambatnya lima tahun sejak Undang-undang ini diundangkan". 


\begin{tabular}{|c|c|}
\hline $\begin{array}{l}\text { Perubahan } \\
\text { Peraturan } \\
\text { Perundang- } \\
\text { undangan bidang } \\
\text { Peradilan Tata } \\
\text { Usaha Negara Data } \\
\text { Perubahan }\end{array}$ & $\begin{array}{l}\text { Rumusan Pasal / Undang- } \\
\text { undang Baru }\end{array}$ \\
\hline $\begin{array}{l}\text { Pasal } 24 \text { Ayat (2) UUD } \\
\text { NRI Tahun } 1945\end{array}$ & $\begin{array}{l}\text { Kekuasaan kehakiman dilakukan } \\
\text { oleh sebuah Mahkamah Agung dan } \\
\text { badan peradilan umum, lingkungan } \\
\text { peradilan agama, lingkungan } \\
\text { peradilan militer, lingkungan } \\
\text { peradilan tata usaha negara, dan } \\
\text { oleh sebuah Mahkamah Konstitusi. }\end{array}$ \\
\hline Kekuasaan Kehakiman & $\begin{array}{l}\text { 1. Undang-Undang Nomor } 4 \\
\text { Tahun } 2004 \text { tentang Kekuasaan } \\
\text { Kehakiman } \\
\text { 2. Undang-Undang Nomor } 48 \\
\text { Tahun } 2009 \text { tentang kekuasaan } \\
\text { kehakiman }\end{array}$ \\
\hline Mahkamah Agung & $\begin{array}{l}\text { 1. Undang-Undang No. } 5 \text { Tahun } \\
\text { 2004 tentang Mahkamah Agung } \\
\text { 2. Undang-Undang No. } 3 \text { Tahun } \\
\text { 2009 tentang Mahkamah Agung }\end{array}$ \\
\hline
\end{tabular}




\begin{tabular}{|l|l|l|}
\hline $\begin{array}{l}\text { Peradilan Tata Usaha } \\
\text { Negara }\end{array}$ & $\begin{array}{l}\text { 1. Undang-Undang No. 9 Tahun } \\
\text { 2004 Peradilan TUN } \\
\\
\text { 2. Undang-Undang Nomor 51 } \\
\text { Tahun 2009 Peradilan TUN }\end{array}$ \\
\hline
\end{tabular}

Tabel 1. Perubahan Undang-Undang yang Mengatur

Kekuasaan Kehakiman dan Mahkamah Agung. Sumber: Himawan Estu Bagijo, Negara Hukum \& Konstitusi

Eksistensi PTUN dirasakan semakin strategis seiring dengan perkembangan hubungan antara pemerintah dan masyarakat. Berbagai persoalan yang muncul dalam relasi antara pemerintah dan masyarakat tidak saja hadir dalam format hubungan antara penguasa dengan swasta yang manifestasinya adalah konflik antara pemerintah dengan badan hukum privat.

Keputusan Tata Usaha Negara sebagai obyek sengketa PTUN. Obyek sengketa menjadi bagian penting untuk menentukan berfungsinya peradilan akan sebuah perkara, hal ini berkaitan erat dengan "kompetensi absolut" lembaga peradilan. Kompetensi Absolut di PTUN terdapat dalam Pasal 47 UU No. 5 Tahun 1986 tentang PTUN yang menentukan pengadilan bertugas dan berwenang memeriksa, memutus dan menyelesaikan sengketa TUN. Alat ukur pengujian untuk menilai apakah sebuah keputusan adalah keputusan TUN, maka ketentuan Pasal 1 angka 3 harus dijadikan dasar rujukan. 
Rumus lengkapnya berikut ini:

Keputusan Tata Usaha Negara adalah suatu penetapan tertulis yang dikeluarkan oleh Badan atau Pejabat Tata Usaha Negara yang berisi tindakan hukum Tata Usaha Negara yang berdasarkan peraturan perundang-undangan yang berlaku, yang berisi konkret, individual, dan final yang menimbulkan akibat hukum bagi seseornag atau badan hukum perdata.

Tentang kompetensi absolut peradilan TUN dapat diskemakan sebagai berikut :

Sengketa TUN $\longrightarrow$ Pasal 1 angka 4
1. Bidang TUN $\longrightarrow$ Pengertian Bidang Tata Usaha Negara
Pasal 1 angka 1
2. Antara Pejabat TUN x Orang/ Badan Hukum Perdata
$\rightarrow$ Pengertian Pejabat Pasal 1 angka 2
3. Akibat adanya Keputusan TUN temasuk kepegawaian
$\rightarrow$ pengertian Keputusan TUN (Pasal 1 angka 3+ Pasal
3)- Ps.2
Keputusan Tata Usaha Negara tersebut berlaku di PUSAT
dan/atau di DAERAH

Tabel 2. Skema Kompetensi Peradilan Tata Usaha Negara Sumber: Himawan Estu Bagijo, Makalah.

Untuk mempertajam konsep, dipergunakan pengertian besluit sebgai bahan perbandingan yang dirujuk 
dalam Algemene wet Bestuursrecht selanjutnya disingkat AwB. Ketentuan Pasal 1 angka 3 AWB, mengatur sebagai berikut "een schriftelijke van een bestuursorgaan, inhoundende en publiekretelijke rechtshandeling" besluit/ keputusan pemerintah adalah penetapan tertulis dari suatu organ pemerintahan yang berisikan suatu perbuatan hukum publik. Terhadap rumusan Pasal 1 angka 3 AwB tersebut, Ten Berge mengemukakan tiga (3) unsur penting "besluit”, yaitu : "schriftelijke beslissing van een rechtshandeling " (tindakan hukum dalam bentuk keputusan pemerintah tertulis), "wilsuting/wilsvorming" (pembentukan kehendak/ pernyataan kehendak) “publiekrechtelijk" (unsur tindakan hukum publik). ${ }^{26}$ Memperhatikan alur pikir Ten Berge, nampak bahwa dalam sebuah "besluit" yang dipentingkan adalah unsur tertulis, perumusan kehendak dan unsur tindakan hukum publik. (Cetak Tebal miring dari penulis)

Tentang sifat tertulisnya sebuah keputusan, dinyatakan Ten Berge sebagai berikut "Het overgroote deel van de besluiten in schriftelijk" (bagian terbesar dari sebuah keputusan pemerintah adalah sifatnya yang tertulis). ${ }^{27}$ Secara tegas dinyatakan : "zonder schriftelijk vorm kunnen besluiten moeilijk bekendgemaakt worden aan grote groepen van personen, en zonder bekenmaking dee kunen ze niet gelden. Ook het overgroot deel van beshickingen is schriftelijk" (tanpa

\footnotetext{
${ }^{26}$ Ten Berge, et.al., Bestuuren door de overheid, (Zwole, Tjeenk Willing, 1996), 138

${ }^{27}$ Ibid, 139
} 
bentuk tertulis, keputusan-keputusan pemerintah sulit dapat diketahui oleh sebagian besar orang, dan tanpa dikethaui oleh sebagian besar orang, dan tanpa diketahui, keputusan pemerintah itu tidak dapat berlaku. Jadi bagian terbesar dari keputusan pemerintahan adalah bentuknya tertulis).

Bagaimana dengan keputusan penolakan ? (keputusan tata usaha negara fiktif negatif sebagaimana diatur dalam Pasal 3 UU Peradilan TUN). Mengenai persoalan ini, pengaturan dalam AWB dikaitkan dengan masalah upaya hukum dalam bentuk keberatan dan banding yang diatur dalam Pasal 6 angka 2 AWB sebagai berikut :28

Voor de toepassing van wettelijk voorschriften over bezwar en beroep worden met enn besluit gelijkgesteid :

a. De schrittelijk weigering een besluit te nemen, en

b. Het niet tijdig nemen van een besluit.

(Terj. untuk menerapkan ketentuan perundangan tentang keberatan dan banding, maka disamakan dengan keputusan pemerintah).

a. Penolakan secara tertulis untuk mengambil suatu keputusan, dan

b. Tidak mengambil suatu keputusan pada waktunya.

\footnotetext{
${ }^{28}$ Himawan Estu Bagijo, Pengujian Keputusan Tata Usaha Negara Masalah dan Tantangannya, Makalah disampaikan dalam Simposium Nasional diselenggarakan oleh Fak. Hukum UNEJ bekerjasama dengan Asosiasi Pengajar Hukum Acara Mahkamah Konstitusi (APHAMK) dan Hans Seidel Foundation (HSF), di Hotel Equator Surabaya tanggal 8-10 Maret 2013, 5
} 
Jadi sifat tertulisnya keputusan sangat erat kaitannya dengan persolan kepastian hukum bagi pihak yang berkepentingan dalam melakukan upaya hukum. Hal ini secara tegas dinyatakan Ten Berge sebagai berikut : Die ies van schriftelijkheid staat ini rechtstreeks verband met de rechtzkerheids (penetapan asas tertulis berkaitan dengan persoalan kepastian hukum). ${ }^{29}$ Sifat tertulisnya suatu keputusan pemerintahan tidak perlu diperdebatkan, lebih jauh jika dikaitkan dengan bentuknya atau format tertentu. Yang dipentingkan adalah adanya pejabat TUN yang menetapkan, jelas maksud dan tujuan ditetapkannya keputusan; jelas subjek yang dituju oleh keputusan dan terdapat tanggal terbitnya surat/ keputusan.

Unsur pernyataan kehendak/ pembentukan kehendak (beslissing/wilsuiting) dari sebuah beschikking secara jelas dinyatakan oleh Ten Berge sebagai berikut :

Pemikiran tersebut mengungkapkan, bahwa een besluit impliceert een beslissing, dat wil zeggen een wilsuiting die gericht is op toegevoegde waarde. Die toegevoegde waarde bij een besluit stukje extra normstelling dat er zonder die beslissing niet zou zijn. Een besluit in begin tus senschakel van de "gelede normstelling"3o

\footnotetext{
${ }^{29}$ Ten Berge, op. cit, 142

${ }^{30}$ Ibid, 140 (Terj. suatu keputusan tertulis termasuk keputusan pemerintah dapat dikatakan pembentukan kehendak untuk nilai tambah keputusan pemerintahan
} 
Suatu keputusan sangat erat kaitannya dengan "kehendak untuk menetapkan kelakuan atas dasar aturan hukum yang telah ada”. Aspek wewenang yang dimiliki oleh organ pemerintah tersebut akan menjadi batas ruang lingkup isi keputusan yang dapat dibentuk..$^{31}$ Sebagai bahan bandingan, berikut dikemukakan pemikiran Philipus $\mathrm{M}$. Hadjon tentang "beslissing” berkaitan dengan karakter hukum akta Pejabat Pembuat Akta Tanah (selanjutnya disebut dengan PPAT). Suatu "beslissing” mengandung suatu wilsvorming (pernyataan kehendak dari pejabat yang bersangkutan). Akta dalam pengertian surat yang digunakan sebagai alat bukti tidak mengandung suatu beslissing, yang ada adalah wilsvorming dari pihak yang mengikatkan dirinya dan bukan wilsvorming dari PPAT yang dapat dituangkan dalam suatu "beslissing". Dengan demikian, kesimpulan pertama dapat ditegaskna bahwa akta PPAT bukan keputusan suatu "besluit". Dengan demikian pula berati bahwa akta PPAT bukan keputusan TUN karena keputusan TUN adalah salah satu "besluit". ${ }^{22}$

Mengacu pada kedua pendapat tersebut, maka sangatlah jelas bahwa karakter hukum besluit sebagai

tidak ada artinya. Sebuah keputusan pemerintahan tidak ada artinya. Sebuah keputusan pemerintahan adalah sebuah mata rantai dari norma sebelumnya).)

${ }^{31}$ Himawan Estu Bagijo, loc. cit.

${ }^{32}$ Philipus M. Hadjon, Akta PPAT bukan Keputusan Tata Usaha Negara, Surabaya, Makalah Diskusi Ilmiah oleh Fakultas Hukum UNAIR dan Ikatan Notaris Indonesia Daerah Jawa Timur, Tanggal 1 Juni 1996, 4 
manifestasi dari "wilsvorming" (pernyataan kehendak), maka kehendak yang mewarnai isu/substansi dari "beschikking" tersebut haruslah berasal dari pejabat yang berwenang. Sehubung dengan itu, maka harus dapat diukur kehendak penguasa yang dituangkan dalam keputusan tersebut.

Peradilan TUN dibentuk tiada lain adalah sebagai bagian pembangunan hukum di Indonesia. Peradilan TUN menyidangkan sengketa yang timbul dalam bidang tata usaha negara, tujuannya yakni memberikan perlindungan kepada rakyat pencari keadilan, yang merasa dirinya dirugikan akibat suatu keputusan tata usaha negara. Sehingga keadilan dapat dirasakan oleh semua masyarakat.

Kepatuhan Hukum Pejabat Tata Usaha Negara terhadap Asas-Asas Pemerintahan yang Baik.

Asas-Asas umum pemerintahan adalah suatu asas yang menjunjung tinggi norma kesusilaan, kepatutan dan aturan hukum. Asas-asas ini tertuang pada UU No. 28 Tahun 1999 tentang Penyelenggaraan Negara yang Bersih dan Bebas KKN. Asas hukum merupakan jantung dari aturan-aturan hukum, asas hukum menjadi titik tolak untuk berpikir, membentuk dan menginterpretasikan hukum. Beberapa istilah intuk menyebut asas pemerintahan yang baik ini bermacam-macam, misalnya di Belanda dikenal dengan sebutan Algemene Beginselen van Behoorlijke Bestuung (ABBB), di Inggris yang menganut common law dikenal 
dnegan sebutan The Principal of Natural Justice, di Perancis diistilahkan Les Principaux Generaux du Dariorit Coutumier Publique, di Belgia disebut Algemene Rechtsbeginselen, di Jerman dinamakan Verfassung Sprinzipien, dan di Indonesia lebih dikenal dengan sebutan Asas-Asas Pemerintahan yang Baik.

Good governance bertalian erat atau mempunyai hubungan interdependent dengan clean governmet, karena dalam tinjauan filosofis suatu pemerintahan yang baik (good goverment) dengan sendirinya akan melahirnya pemerintahan yang bersih (clean government) atau dengan kata lain clean governemet merupakan prasyarat bagi proses suatu good governance. Meskipun demikian, kenyataannya sering ditemukan pemerintahan yang baik belum tentu merupakan pemerintahan yang bersih. ${ }^{33}$

Tujuan menjadi menjadi negara yang bersih maka diperlukan suatu negara yang baik/ layak terlebih dahulu. Jazim Hamidi menerangkan sebagaimana di kutip oleh Solihati dkk, ${ }^{34}$ Asas-Asas Umum Pemerintahan yang Layak merupakan nilai-nilai etik yang hidup dan berkembangan dalam lingkungan HAN. Asas-Asas Umum Pemerintahan yang layak berfungsi sebagai pegangan bagi pejabat

33 S.F. Marbun, Eksistensi Asas-Asas Umum Penyelenggaraan Pemerintahan Yang Layak dalam Menjelmakan Pemerintahan yang Baik dan Bersih di Indonesia, Disertasi, (Bandung: Program Pascasarjana Universitas Padjajaran, 2001), 275.

${ }^{34}$ Solihati dkk, Kedudukan dan Fungsi Asas-Asas Pemerintahan yang Layak dalam Memutus Sengketa TUN di PTUN, Makalah, 2 
administrasi negara dalam menjalankan fungsinya, merupakan alat uji bagi hakim administrasi dalam menilai tindakan administrasi negara (yang berwujud beschikking), dan sebagai dasar pengajuan gugatan bagi penggugat. Sebagian besar asas-asas umum pemerintahan yang layak masih merupakan asas-asas yang tidak tertulis, abstrak, dan dapat digali dalam praktik kehidupan masyarakat. Sebagian asas yang lain sudah menjadi kaidah hukum tertulis dan terpencar dalam berbagai peraturan hukum positif.

Asas atau norma hukum yang dijadikan suatu pedoman dalam pelaksanaan pemerintahan memang terasa masih kurang jelas, karena asas ini memang suatu pedoman yang masih umum. Peneliti menganggap perlu untuk mengetahui apa yang dimaksud dengan asas. W.J.S. Poerwadarminta memberikan pengertian asas adalah 1) Dasar, alas, pedoman; misalnya: batu yang baik untuk asas rumah; 2) sesuatu kebernaran yang menjadi pokok atau tumpuan berpikir (berpendapat dan sebagainya), misalnya: bertentang dengan asas-asas hukum pidana; 3) cita-cita yang menjadi dasar (perkumpulan, negara dan sebagainya), misalnya: membicarakan asas dan tujuan perserikatan. ${ }^{35}$

Berbeda halnya dengan pengertian asas yang diutarakan oleh C.W. Paton, ${ }^{36}$ "A Principle is the broad reason,

\footnotetext{
35 W.J.S. Poerwadarminta, Kamus Umum Bahasa Indonesia, (Jakarta: Balai Pustaka, 2002), 60-61.

${ }^{36}$ Mahadi, Falsafah Hukum: Suatu Pengantar, (Bandung: Alumni, 2003), 122.
} 
which lies at the base of rule of law". (Terj. Asas adalah suatu alam pikiran yang dirumuskan secara luas dan yang mendasar adanya suatu norma hukum).

Asas-Asas umum pemerintahan yang baik ini merupakan konsep terbuka (open begrif), karena itu akan berkembang dan disesuaikan dengan ruang dan waktu dimana konsep ini berada. Menurut Jazim Hamidi37, pengertian asas-asas umum pemerintahan yang layak/baik adalah sebagai berikut:

a. asas-asas umum umum pemerintahan yang layak merupakan nilai-nilai etik yang hidup dan berkembang dalam lingkungan hukum administrasi negara.

b. Asas-asas umum pemerintahan yang layak berfungsi sebagai pegangan bagi pejabat administrasi negara dalam menjalankan fungsinya, merupakan alat uji bagi hakim administrasi dalam menilai tindakan administrasi negara (yang berwujud penetapan/beschikking), dan sebagai dasar pengajuan gugatan bagi pihak penggugat.

c. Sebagian besar asas-asas umum pemerintahan yang layak masih merupakan asas-asas yang tidak tertulis, masih abstrak, dan dapat digali dalam praktik kehidupan masyarakat.

d. Sebagian asas yang lain sudah menjadi kaidah hukum 
tertulis dan terpencar dalam berbagai peraturan hukum positif.

Makna asas-asas hukum publik yang pertama atau asas-asas umum pemerintahan yang baik adalah "asas-asas hukum tidak tertulis yang harus diperhatikan oleh badan atau pejabat administrasi negara dalam melakukan tindakan hukum yang akan dinilai kemudian oleh hakim administrasi”.38

Hukum publik mempunyai wewenang yang selalu dikaitkan pada jabatan publik yang merupakan organ pemerintah (bestuurs organ) dan menjalankan wewenangnya dalam fungsi pemerintahan dan segala tindakannya selalu dilakukan untuk kepentingan umum. Asas pemerintahan menurut hukum (rechmatig bestuur) menurut Philipus M. Hadjon, ${ }^{39}$ merumuskan asas pemerintahan menurut hukum (rechtmatig bestuur), khususnya menyangkut penerbitan keputusan tata usaha negara, sebagai berikut:

1. Asas bertindak sesuai dengan peraturan perundangundangan (wetmatigheid). Kesesuaian tersebut menyangkut wewenang, prosedur dan substansi keputusan;

2. Asas "tidak menyalahgunakan wewenang untuk tujuan

$3^{8}$ Olden Bidara, Asas-Asas Umum Penyelenggaraan Pemerintahan Yang Layk Dalam Teori dan Praktek Pemerintahan, dalam Himpunan Makalah Asas-Asas Umum Pemerintahan yang Baik (AAUPB), Penyusun: Paulus Efeendi Lotulung, (Bandung: Citra Aditya Bhakti, 1994), 80.

39 Philipus M. Hadjon, op. cit, 
lain" (larangan detournement de pouvoir);

3. Asas bertindak rasional, wajar atau dapat dirumuskan sebagai asas tidak bertindak sewenang-wenang. Bertindak sesuai dengan asas-asas umum pemerintahan yang layak.

Penyelesaian sengketa Tata Usaha Negara lebih dikenal 2 (dua) macam jalan yakni sebagai berikut:

1. Melalui Upaya Adminsitrasi (vide Pasal 48 jo. Pasal 51 Ayat (3) UU No. 5 Tahun 1986 yang telah dirubah dan ditambah dengan UU No. 9 Tahun 2004, UU No. 51 Tahun 2009 tentang Peradilan Tata Usaha Negara Upaya administrasi adalah suatu prosedur yang dapat ditempuh dalam menyelesaikan masalah sengketa Tata Usaha Negara oleh seseorang atau badan hukum perdata apabila ia tidak puas terhadap suatu Keputusan Tata Usaha Negara, dalam lingkungan administrasi atau pemerintah. Bentuk upaya administrasi antara lain sebagai berikut:

a. Keberatan, yaitu prosedur yang dapat ditempuh oleh seseorang atau badan hukum perdata yang tidak puas terhadap Keputusan Tata Usaha Negara, yang penyelesaian sengketa Tata Usaha Negara sebagai akibat dikeluarkannya keputusan tata usaha negara tersebut dilakukan sendiri oleh Badan atau pejabat tata usaha negara yang mengeluarkan keputusan tata 
usaha negara yang dimaksud. ${ }^{40}$

b. Banding Administrasi, yaitu penyelesaian upaya administrasi yang dilakukan oleh instansi atasan atau instansi lain dari yang mengeluarkan Keputusan yang bersangkutan. ${ }^{41}$

2. Melalui Gugatan (vide Pasal 1 Angka 5 jo. Pasal 53 UU No. 5 Tahun 1986 yang telah dirubah dan ditambah dengan UU No. Tahun 2004 dan UU No. 51 Tahun 2009 tentang Peradilan Tata Usaha Negara.

Apabila di dalam ketentuan perundang-undangan yang berlaku tidak ada kewajiban untuk menyelesaikan sengketa Tata Usaha Negara tersebut melalui Upaya Administrasi, maka seseorang atau Badan hukum perdata dapat mengajukan gugatan ke Pengadilan Tata Usaha Negara. ${ }^{42}$

Asas Asas Umum Pemerintahan yang Baik ini pada awalnya dikemukakan oleh Crince Le Roy, yang di Indonesia kemudian diadopsi dan dikembangkan oleh Kuntjoro Purbopranoto. Kuntjoro Purbopranoto mengutip tulisan Crince Le Roy, dan menambahkan pendapatnya sendiri sehingga menjadi tiga belas asas yang dikandung dalam AAUPB, yaitu;43 (1) Asas kepastian hukum (principle of legal

\footnotetext{
$4^{40}$ R. Wiyono, op. cit, 110.

${ }^{41} \mathrm{Ibid}, 111$.

${ }^{42}$ Ibid, 117 .

43 Kuntjoro Purbopranoto, Beberapa Catatan Hukum Tata Pemerintahan dan Peradilan Administrasi Negara, (Bandung: Alumni, 1981), 28-29.
} 
security); (2) Asas keseimbangan (principle of proportionality); (3) Asas bertindak cermat (principle of carefullness); (4) Asas motivasi untuk setiap keputusan pejabat administrasi/ tata usaha negara (priciple of motivasion); (5) Asas tidak boleh mencampuradukan kewenangan (principle of non misuse of competence); (6) Asas-Asas kesamaan dalam mengambil keputusan (principle of equality); (7) Asas permainan yang layak (principle of fair play); (8)Asas keadilan atau kewajaran (principle of arbitrariness); (9) Asas menanggapi pengharapan yang wajar (principle of meeting reised expectation); (10) Asas meniadakan akibat-akibat suatu keputusan yang batal (principle of undoing the consequence of unnulled decisision); (11) Asas perlindungan atas pandangan hidup (cara hidup) pribadi (principle of protecting the personal way of life); (12)Asas kebijaksanaan (principle of sapiently); (13) Asas penyelenggaraan kepentingan umum (principle of public service).

Lebih lanjut mengenai AAUPB tersebut, Pasal 3 Undang-undang Nomor 28 Tahun 1999 Tentang Penyelenggara Negara Yang Bersih dan Bebas dari Korupsi, Kolusi, dan Nepotisme telah menjadikan asas-asas hukum publik menjadi suatu norma hukum publik. Ketentuan dalam Pasal 3 itu menyatakan bahwa Asas-Asas Umum Penyelenggaraan Negara (AAUPN) meliputi: (1) Asas Kepastian Hukum; (2) Asas Tertib Penyelenggaraan Negara; 
(3) Asas Kepentingan Umum; (4) Asas Keterbukaan; (5) Asas Proporsional; (6) Asas Profesional; dan (7) Asas Akuntabilitas.

Asas-asas pemerintahan yang baik dapat dipahami sebagai suatu asas-asas yang menjadi dasar dan tata cara dalam penyelenggaraan pemerintahan yang baik, yang dengan cara tersebut dalam penyelenggaraan pemerintahan menjadi baik, sopan, adil dan terhormat, bebas dari kezaliman, pelanggaran peraturan, tindakan penyalahgunaan wewenang dan tindakan sewenang-wenang. Sehingga dapat dipahami bahwa asas-asas pemerintahan yang baik sudah semestinya menjadi pedoman bagi badan/pejabat Tata Usaha Negara dalam menjalankan fungsinya, sehingga mampu mewujudkan pemerintahan yang bersih dan bebas dari KKN serta dapat memberikan publik yang sangat baik.

\begin{tabular}{|l|l|}
\hline $\begin{array}{l}\text { Asas-Asas Umum } \\
\text { Pemerintahan } \\
\text { yang Baik (AAUPB) }\end{array}$ & $\begin{array}{l}\text { Norma dalam Undang-Undang } \\
\text { Nomor } 5 \text { Tahun } 1986 \text { tentang } \\
\text { Peradilan Tata Usaha Negara } \\
\text { serta Pelaksanaan Putusan } \\
\text { Peradilan Tata Usaha Negara. }\end{array}$ \\
\hline 1. Asas Kepastian & $\begin{array}{l}\text { Asas ini menghormati hak yang } \\
\text { diperoleh seseorang berdasarkan } \\
\text { suatu keputusan, namun pejabat } \\
\text { tata usaha Negara dalam } \\
\text { melaksanakan putusan peradilan } \\
\text { tata usaha Negara yang sudah }\end{array}$ \\
\hline
\end{tabular}




\begin{tabular}{|c|c|}
\hline & $\begin{array}{l}\text { berkekuatan inkracht tidak } \\
\text { dilaksanakan. Hal ini } \\
\text { menyebabkan pejabat tata usaha } \\
\text { Negara telah mencederai asas } \\
\text { kepastian hukum. }\end{array}$ \\
\hline $\begin{array}{l}\text { 2. Asas } \\
\text { Keseimbangan }\end{array}$ & $\begin{array}{l}\text { Dalam asas ini dikehendaki } \\
\text { adanya keseimbangan antara } \\
\text { hukuman dan kelalaian } \\
\text { seseorang. Pejabat tata usaha } \\
\text { Negara dalam memutuskan suatu } \\
\text { kebijakan } \\
\text { mempertimbangkan anang } \\
\text { hukuman dan kelalaian pejabat } \\
\text { di bawahnya. }\end{array}$ \\
\hline $\begin{array}{l}\text { 3. Asas Kesamaan } \\
\text { dalam } \\
\text { Mengambil } \\
\text { Keputusan }\end{array}$ & $\begin{array}{l}\text { Asas ini menghendaki agara } \\
\text { badan/ pejabat tata usaha Negara } \\
\text { harus mengambil tindakan yang } \\
\text { sama dengan kasus-kasus yang } \\
\text { faktanya sama. Pejabat tata } \\
\text { Usaha Negara/ Bupati/Walikota } \\
\text { antara satu dengan yang lain } \\
\text { dalam memutuskan suatu } \\
\text { keputusan sering kali kurang } \\
\text { obyektif, karena ada tendensi ke }\end{array}$ \\
\hline
\end{tabular}




\begin{tabular}{|c|c|}
\hline & subyektif. \\
\hline $\begin{array}{l}\text { 4. Asas Bertindak } \\
\text { Cermat }\end{array}$ & $\begin{array}{l}\text { Asas ini menghendaki agar } \\
\text { badan/ pejabat tata usaha Negara } \\
\text { harus bertindak cermat atau hati- } \\
\text { hati. Dalam praktik administrasi } \\
\text { di tingkat pusat maupun daerah } \\
\text { pejabat tata usaha Negara dalam } \\
\text { memutuskan suatu Surat } \\
\text { Keputusan/Surat Penetapan yang } \\
\text { bisa berbentuk Keputusan } \\
\text { Bupati, Peraturan Bupati dan } \\
\text { lain-lain, kurang hati-hati dalam } \\
\text { memutuskan. Hal ini terbukti } \\
\text { dengan banyaknya penetapan } \\
\text { dan putusan pejabat TUN yang di } \\
\text { gugat di Peradilan Tata Usaha } \\
\text { Negara. }\end{array}$ \\
\hline $\begin{array}{l}\text { 5. Asas tidak } \\
\text { melampaui } \\
\text { dan/atau } \\
\text { Mencampuraduk } \\
\text { kan Kewenangan }\end{array}$ & $\begin{array}{l}\text { Asas ini bermaksud agar tidak } \\
\text { boleh menggunakan kewenangan } \\
\text { itu untuk tujuan lain selain } \\
\text { daripada tujuan yang telah } \\
\text { ditetapkan untuk kewenangan } \\
\text { itu. Pada praktik pelaksanaan } \\
\text { asas ini dapat ditemui bahwa } \\
\text { pejabat tata usaha Negara dalam }\end{array}$ \\
\hline
\end{tabular}




\begin{tabular}{|c|c|}
\hline & $\begin{array}{l}\text { melaksankan tugasnya sebagai } \\
\text { pejabat pangreh menggunakan } \\
\text { kewenangannya untuk tujuan } \\
\text { politiknya pribadi. Hal ini } \\
\text { terbukti dengan banyak Pegawai } \\
\text { Negeri Sipil yang berbeda haluan } \\
\text { saat pemilihan kepala daerah } \\
\text { yang dimutasi, karena tidak } \\
\text { memilih pejabat tata usaha } \\
\text { Negara tersebut. }\end{array}$ \\
\hline $\begin{array}{l}\text { 6. Asas Meniadakan } \\
\text { Akibat Suatu } \\
\text { Keputusan yang } \\
\text { Batal }\end{array}$ & $\begin{array}{l}\text { Asas ini menghendaki agar } \\
\text { kedudukan seseorang di pulihkan } \\
\text { kembali sebagai akibat dari } \\
\text { keputusan yang batal. Dalam } \\
\text { putusan PTUN yang } \\
\text { dimenangkan oleh penggugat } \\
\text { yang sudah berkekuatan hukum } \\
\text { tetap. Bupati/Walikota tetap } \\
\text { tidak memulihkan kedudukan } \\
\text { penggugat, karena jabatan } \\
\text { penggugat telah di isi oleh } \\
\text { pejabat lain. }\end{array}$ \\
\hline $\begin{array}{l}\text { 7. Asas } \\
\text { Penyelenggaraan }\end{array}$ & $\begin{array}{llr}\text { Kepentingan } & \text { umum meliputi } \\
\text { kepentingan } & \text { nasional dalam }\end{array}$ \\
\hline
\end{tabular}




\begin{tabular}{|c|c|}
\hline $\begin{array}{l}\text { Kepentingan } \\
\text { Umum }\end{array}$ & $\begin{array}{l}\text { nasional dalam arti kepentingan } \\
\text { bangsa, Negara, masyarakat. } \\
\text { Kepentingan umum mengatasi } \\
\text { kepentingan individu, golongan } \\
\text { dan daerah. Dalam praktik } \\
\text { pelaksanaan keputusan pejabat } \\
\text { tata usaha Negara lebih } \\
\text { mementingkan kepentingan } \\
\text { pribadi dan golongan politiknya. } \\
\text { Hal ini tentunya sangat } \\
\text { bertentangan dengan asas } \\
\text { Penyelenggaraan kepentingan } \\
\text { umum. }\end{array}$ \\
\hline 8. Asas Keadilan & $\begin{array}{l}\text { Setiap penyelenggaraan } \\
\text { administrasi pemerintahan harus } \\
\text { mencerminkan keadilan secara } \\
\text { proporsional bagi setiap warga } \\
\text { Negara. Pejabat tata usaha } \\
\text { Negara dalam memberikan suatu } \\
\text { keputusan masih partial, dan } \\
\text { memihak salah satu golongan. }\end{array}$ \\
\hline
\end{tabular}

Tabel 2.3. Asas-Asas Umum Pemerintahan yang Baik

Sumber: Penulis olah dari beberapa literatur.

Perbuatan melanggar hukum oleh badan atau pejabat administrasi negara dalam hukum administrasi negara adalah 
perbuatan hukum publik bersegi satu (vertikal) dan perbuatan hukum publik bersegi dua (horisontal) yang dilakukan oleh badan atau pejabat administrasi negara melanggar hukum berdasarkan putusan lembaga peradilan lain (diluar peradilan administrasi negara (PTUN)) yang sudah inkracht van gevijsde, yurisprudensi, asas-asas hukum publik baik asas-asas umum pemerintahan yang baik atau asas-asas umum penyelenggaraan negara maupun asas-asas hukum nasional, hukum kebiasaan atau hukum adat, dan hak asasi manusia.

Dengan demikian untuk tertibnya teknis dan administrasi peradilan serta integrasi, effektifitas dan effisiensi penegakkan hukum administrasi negara kedepannya perlu direvisi Undang-undang Nomor 5 Tahun 1986 jo. Undang-undang Nomor 9 Tahun 2004 dan Undang-undang Nomor 51 Tahun 2009 Tentang PTUN, terutama mengenai kewenangan peradilan administrasi negara (PTUN) sesuai philosopisnya dalam menyelesaikan sengketa administrasi negara yaitu dengan menjadikan "perbuatan hukum publik oleh badan atau pejabat administrasi yang melanggar hukum” sebagai objek sengketa di peradilan administrasi negara (PTUN). 


\section{Kesimpulan}

Berdasarkan pembahasan di atas, penulis menyimpulkan sebagai berikut: Pertama, Konsep kepatuhan hukum pejabat Tata Usaha Negara adalah konsisten melaksanakan putusan Peradilan Tata Usaha Negara dalam rangka penyelenggaraan asas-asas pemerintahan yang baik. Kepatuhan dilandasi oleh kesadaran hukum. Kesadaran hukum dan kepatuhan hukum sangat diperlukan bagi penegakan hukum di Indonesia. Kesadaran dan kepatuhan hukum mutlak diperlukan oleh setiap warga negara, sebagaimana tujuan dari adanya hukum. Kepatuhan terhadap peraturan perundang-undangan membuktikan bahwa rakyat mulai sadar hukum. Pejabat Tata Usaha Negara sebagai warga negara yang mempunyai jabatan sebagai pejabat pangreh perlu ditekankan untuk mematuhi putusan peradilan sesuai dengan asas-asas pemerintahan yang baik dan juga sebagai contoh terhadap warga negara yang lain. Kedua, Berdasarkan Pasal 116 Undang-Undang Nomor 5 Tahun 1986 tentang Peradilan Tata Usaha Negara dapat dipahami bahwa pengaturan kepatuhan pejabat Tata Usaha Negara untuk melaksanakan putusan Peradilan Tata Usaha Negara tidak sesuai dengan Asas-Asas Pemerintahan yang Baik.

\section{Daftar Pustaka}

A. Hamid S.Attamimi, Teori Perundang-Undangan Indonesia, 
Suatu Sisi Ilmu Pengetahuan Perundang-Undangan yang Menjelaskan dan Menjernihkan Pemahaman, Pidato di Fakultas Hukum Universitas Indonesia, Jakarta, 25 April 1992

Arief Sidharta, Refleksi Tentang Struktur Ilmu Hukum, Bandung: Mandar Maju

Bayu Dwi Anggono, Perkembangan Pembentukan UndangUndang Di Indonesia, Jakarta: Konstitusi Press, 2014

C.W. Star Busmann, Hoofdstukken van Burgerlijke Rechtsvordering

Himawan Estu Bagijo, Pengujian Keputusan Tata Usaha Negara Masalah dan Tantangannya, Makalah disampaikan dalam Simposium Nasional diselenggarakan oleh Fak. Hukum UNEJ bekerjasama dengan Asosiasi Pengajar Hukum Acara Mahkamah Konstitusi (APHAMK) dan Hans Seidel Foundation (HSF), di Hotel Equator Surabaya tanggal 8-10 Maret 2013

Hukum di Indonesia, https://id.wikipedia.org diakses pada tanggal 1 Pebruari 2016.

I Dewa Gede Atmadja, Ilmu Negara, (Malang: Setara, 2012), hlm. 100.

Johny Ibrahim, Teori dan Metodologi Penelitian Hukum Normatif, Malang : Bayumedia, 2006Peter Mahmud Marzuki, Penelitian Hukum, Jakarta : Kencana, 2008 
Jujun S. Suriasumantri, Filsafat Ilmu: Sebuah Pengantar Populer, (Jakarta: Pustaka Sinara Harapan, 2005

Kompas Edisi terbit Sabtu 1 Desember 2012, "Seorang PNS Kalahkan Bupati”, serta Media Metro Siantar, "Toluto Bayar Rp. 10 Juta Setiap Bulan kepada Erty”, Kamis 29 Nopember 2012.

Kuntjoro Purbopranoto, Beberapa Catatan Hukum Tata Pemerintahan dan Peradilan Administrasi Negara, Bandung: Alumni, 1981

L. Neville Brown, cs, French Administrative Law,fourth edition, (Oxford: Clarendon Press, 1993

Lintong O. Siahaan, Prospek PTUN Sebagai Pranata Penyelesaian Sengketa Administrasi di Indonesia (Studi Tentang Keberadaan PTUN Selama Satu Dasawarsa 1991-2001, Jakarta: Percetakan Negara RI, 2005

Olden Bidara, Asas-Asas Umum Penyelenggaraan Pemerintahan Yang Layk Dalam Teori dan Praktek Pemerintahan, dalam Himpunan Makalah Asas-Asas Umum Pemerintahan yang Baik (AAUPB), Penyusun: Paulus Efeendi Lotulung, Bandung: Citra Aditya Bhakti, 1994

Paulus Effendie Lotulung, Eksistensi Undang-Undang Nomor 5 Tahun 1986 Dalam Menunjang Pemerintahan yang Bersih, Kuat dan Berwibawa dalam "Butir-Butir 
Gagasan Tentang Penyelenggaraan Hukum dan Pemerintahan Yang Layak (Sebuah Tanda Mata Bagi 7o Tahun Prof. Dr. Ateng Syarifudin, S.H.), Bandung: PT. Citra Aditya Baktim 1996

Philipus M. Hadjon, Akta PPAT bukan Keputusan Tata Usaha Negara, Surabaya, Makalah Diskusi Ilmiah oleh Fakultas Hukum UNAIR dan Ikatan Notaris Indonesia Daerah Jawa Timur, Tanggal 1 Juni 1996

Philipus M. Hadjon, et.al, Pengantar Hukum Administrasi Indonesia, Cetakan ketiga, Yogyakarta: Gadjah Mada University Press, 1994

Rekomendasi Ombudsman Republik Indonesia Nomo:003/REK/0899.2009/BS.03/III/2012.

Rumusan Pasal 144 UU Nomor 5 Tahun 1986 yakni : “UndangUndang ini mulai berlaku pada tanggal diundangkan dan penerapannya diatur dengan Peraturan Pemerintah selambat-lambatnya lima tahun sejak Undang-undang ini diundangkan”.

S.F. Marbun, Eksistensi Asas-Asas Umum Penyelenggaraan Pemerintahan Yang Layak dalam Menjelmakan Pemerintahan yang Baik dan Bersih di Indonesia, Disertasi, Bandung: Program Pascasarjana Universitas Padjajaran, 2001

Solihati dkk, Kedudukan dan Fungsi Asas-Asas Pemerintahan yang Layak dalam Memutus Sengketa TUN di PTUN, 
Makalah

Sudikno Mertokusumo, Sejarah Peradilan dan PerundangUndangannya di Indonesia Sejak 1942 dan Apakah Kemanfaatannya Bagi Kita Bangsa Indonesia, Disertasi, Yogyakarta: Liberty, 1983

Surabaya Post Online, Bupati tolak putusan PTUN, http://www.surabayapost.co.id, diakses tanggal 28 Juni 2015.

Ten Berge, et.al., Bestuuren door de overheid, Zwole, Tjeenk Willing, 1996

Undang-Undang Dasar Negara Republik Indonesia Tahun 1945

Undang-Undang Dasar Negara Republik Indonesia Tahun 1945 Pasal 24 Ayat (2) menyatakan: Kekuasaan kehakiman dilakukan oleh sebuah Mahkamah Agung dan badan peradilan yang berada di bawahnya dalam lingkungan peradilan umum, lingkungan peradilan agama, lingkungan peradilan militer, lingkungan peradilan tata usaha negara, dan oleh sebuah Mahkamah Konstitusi.

Undang-Undang No. 17 Tahun 2005 tentang Rencana Jangka Panjang Nasional Tahun 2005-2025-Lampiran Bab IV tentang Arah - Tahapab dan Prioritas Pembangunan Jangka Panjang Tahun 2005-2025 -IV.1.2 Mewujudkan Bangsa yang Berdaya Saing -Huruf E 
Reformasi Hukum dan Birokrasi.

UU No. 51 Tahun 2009 tentang Perubahan Kedua Atas UU No. 5 Tahun 1986 tentang Peradilan Tata Usaha Negara, Pasal 1 Angka 9 :"Keputusan Tata Usaha Negara adalah suatu penetapan tertulis yang dikeluarkan oleh badan atau pejabat tata usaha negara yang berisi tindakan hukum tata usaha negara yang berdasarkan peraturan perundang-undangan yang berlaku, yang bersifat konkret, individual, dan final, yan menimbulkan akibat hukum bagi seseorang atau badan hukum perdata".

W. Riawan Tjandra " Peradilan Tata Usaha Negara, Mendorong Terwujudnya Pemerintahan yang Bersih dan Berwibawa, Yogyakarta: Penerbit Universitas Atmajaya Yogyakarta, 2009

W.J.S. Poerwadarminta, Kamus Umum Bahasa Indonesia, Jakarta: Balai Pustaka, 2002 Mahadi, Falsafah Hukum: Suatu Pengantar, Bandung: Alumni, 2003.

Widodo Ekatjahjana, Negara Hukum, Konstitusi, dan Demokrasi (Dinamika dalam Penyelenggaraan Sistem Ketatanegaraan Republik Indonesia),(Jember: Jember University Press, 2015

www.yomawaperatun.blogspot.com , diakses pada tanggal 1 April 2015. 